\title{
The calcareous nannofossil Prinsiosphaera achieved rock-forming abundances in the latest Triassic of western Tethys: consequences for the $\delta^{13} \mathrm{C}$ of bulk carbonate
}

\author{
N. Preto ${ }^{1,2}$, C. Agnini ${ }^{1,3}$, M. Rigo ${ }^{1,3}$, M. Sprovieri ${ }^{4}$, and H. Westphal ${ }^{2}$ \\ ${ }^{1}$ Department of Geosciences, University of Padova, Via Gradenigo 6, 35131 Padova, Italy \\ ${ }^{2}$ Leibniz Center for Tropical Marine Ecology (ZMT), Bremen, Germany \\ ${ }^{3}$ IGG-CNR, Padova, Italy \\ ${ }^{4}$ IAMC-CNR Torretta Granitola, Trapani, Italy \\ Correspondence to: N. Preto (nereo.preto@unipd.it)
}

Received: 4 April 2013 - Published in Biogeosciences Discuss.: 14 May 2013

Revised: 8 August 2013 - Accepted: 9 August 2013 - Published: 23 September 2013

\begin{abstract}
The onset of pelagic biomineralization was a milestone in the history of the long-term inorganic carbon cycle: as soon as calcareous nannofossils became major limestone producers, the $\mathrm{pH}$ and supersaturation state of the global ocean were stabilized (the so-called mid-Mesozoic revolution). But although it is known that calcareous nannofossils were abundant already by the end of the Triassic, no estimates exist on their contribution to hemipelagic carbonate sedimentation. With this work, we estimate the volume proportion of Prinsiosphaera, the dominant late Triassic calcareous nannofossil, in hemipelagic and pelagic carbonates of western Tethys. The investigated Upper Triassic lime mudstones are composed essentially of microspar and tests of calcareous nannofossils, plus minor bioclasts. Prinsiosphaera had become a significant component of lime mudstones since the late Norian, and was contributing up to ca. $60 \%$ of the carbonate by the late Rhaetian in periplatform environments with hemipelagic sedimentation. The increasing proportion of Prinsiosphaera in upper Rhaetian hemipelagic lime mudstones is paralleled by an increase of the $\delta^{13} \mathrm{C}$ of bulk carbonate. We interpreted this isotopic trend as related to the diagenesis of microspar, which incorporated respired organic carbon with a low $\delta^{13} \mathrm{C}$ when it formed during shallow burial. As the proportion of nannofossil tests increased, the contribution of microspar with low $\delta^{13} \mathrm{C}$ diminished, determining the isotopic trend. We suggest that a similar diagenetic effect may be observed in many Mesozoic limestones with a significant, but not yet dominant, proportion of calcareous plankton.
\end{abstract}

\section{Introduction}

Calcareous nannofossils have contributed significantly to pelagic sedimentation starting in the late Triassic (Bellanca et al., 1995; Bralower et al., 1991; Bown, 1998; Bown et al., 2004; Gardin et al., 2012; Preto et al., 2013). The spreading of calcareous nannofossils had a major consequence on seawater chemistry, as well as on the long-term carbon cycle. Before pelagic biomineralization by calcareous nannofossils, carbon was sequestrated, in the form of calcium carbonate, only in platform areas, i.e., in areally limited portions of the global ocean. This implied a poor stabilization of carbonate species concentrations in seawater and, consequently, a variable seawater $\mathrm{pH}$ before the Triassic. An ocean in this state is, according to Zeebe and Westbroeck (2003), in "Neritan" mode. From the Jurassic on, precipitation of carbonates occurred both on platforms and in open oceans in the form of calcitic tests of planktonic organisms (nannoliths, coccoliths, calcareous dinocysts, and, later on, planktonic foraminifers). An ocean in this state buffers the carbonic acid and the products of its dissociation more efficiently, resulting in a more stable seawater $\mathrm{pH}$ through geological times. It is called an ocean in "Cretan" mode (Zeebe and Westbroeck, 2003), and is similar, for what the carbonate chemistry is concerned, to the modern oceans. Clearly, the switch from the "Neritan" to the "Cretan" mode was a milestone in the evolution of ocean chemistry, and was thus baptized the "mid-Mesozoic revolution" (Ridgwell, 2005). 
But while the importance of this event is widely recognized, its temporal allocation is still vague. Ridgwell (2005) dates this event to sometime within the Jurassic, although with a high degree of uncertainty. However, it is usually understood that abundant calcareous nannofossils first appear in the late Triassic (e.g., Bown, 1998; Erba, 2004; Furin et al., 2006).

Calcareous nannofossils were first described from the hemipelagic carbonates of the Tethys realm by Di Nocera and Scandone (1977) and then by Bellanca et al. (1993, 1995). These authors mostly illustrated unidentified calcispheres, whose structure and diagenetic alteration was subsequently illustrated by Preto et al. (2013). Preto et al. (2012) illustrated coccoliths and nannoliths from Pizzo Mondello in Sicily. In this locality Prinsiosphaera is abundant in the Rhaetian, with other calcareous planktonic forms (coccoliths and calcareous dinocysts) being largely subordinated. A Lower Jurassic (Pliensbachian) portion of the section instead yielded a rich coccolith flora and abundant calcispheres.

Gardin et al. (2012) attempted to pin down precisely the first (common) occurrence of key late Triassic nannofossil taxa as Prinsiosphaera and "coccolithophores". These taxa apparently become common only from the latest Sevatian (upper Norian), i.e., much later than Bralower et al. (1991) suggested for ODP sites 759-761 and 764 on the Wombat Plateau offshore of northwest Australia. The study of Gardin et al. (2012) is based on condensed successions of the Northern Calcareous Alps in Austria, and for the first time provides semi-quantitative estimation of calcareous nannofossil abundances in the Triassic, tightly constrained by conodont biostratigraphy. The quantification approach followed by Gardin et al. (2012), however, can only identify trends in nannofossil abundances, and gives little information on the volume contribution of nannofossils to carbonate sedimentation. Preto et al. (2013) showed that "calcispheres" of uncertain taxonomic affinity become significant components of limestone from the base of the upper Carnian, but their contribution to deep-water carbonate sedimentation is hard to quantify due to strong epitaxial calcite overgrowth.

In this contribution, we examine the distribution of the most common late Triassic nannolith, Prinsiosphaera, in selected successions of the southern Apennines and Sicily. The occurrence of common Prinsiosphaera in Sicily was documented by Preto et al. (2012). Our aim is to provide a quantification of nannofossils' contribution to pelagic and hemipelagic carbonates. This study should thus be considered complementary to that of Gardin et al. (2012), both in terms of methods and because of the different paleogeographical position of the studied successions.

Analyses of the carbon stable isotope composition of bulk carbonate $\left(\delta^{13} \mathrm{C}_{\text {carb }}\right)$ were also performed in order to identify possible correlations between nannofossil abundance and perturbations of the global carbon cycle. The effect of diagenesis was assessed with a combination of geochemical data and petrographic observations.

\section{Geological setting}

For this study, western Tethysian hemipelagic to pelagic carbonates and siliceous carbonates from the basinal domains of the southern Apennines (Lagonegro Basin) and Sicily (Sicanian Basin) were sampled in two representative stratigraphic sections (Fig. 1) that apparently correlate with the increase in abundance of Prinsiosphaera observed in the late Norian by Gardin et al. (2012). The Norian facies are similar in the two areas: nodular cherty limestones with calcified radiolarian molds and thin-shelled bivalves. However, significant differences in the sedimentation between the Lagonegro and Sicanian basins are observed in the late Norian and Rhaetian (latest Triassic), which is our interval of interest. We shall thus describe the typical succession of the two basins separately, also providing the current biostratigraphies.

\subsection{Pizzo Mondello section in the Sicanian Basin}

A periplatform carbonate succession of late Carnian to Jurassic age, belonging to the Sicanian Basin, crops out at Pizzo Mondello in central Sicily (Di Stefano, 1990; Gullo, 1996) (Fig. 1). Its lower portion is exposed on the walls of an abandoned quarry, and was proposed as type section for the Global Boundary Stratotype Section and Point (GSSP) of the Norian (e.g., Muttoni et al., 2004; Balini et al., 2012; Mazza et al., 2012). The upper part is not similarly well exposed, but large intervals of the late Norian to early Jurassic succession can be logged and sampled (Gullo, 1996; Mazza et al., 2012; Preto et al., 2012), and there is no evidence of discontinuities between the measured tracts of the section. For this study, we focused on the late Norian, Rhaetian and early Jurassic portions of the succession (Fig. 2), which are well constrained by conodont biostratigraphy (Mazza et al., 2010, 2012), calcareous nannofossils and radiolarians (Preto et al., 2012). In this interval, the succession is comprised of chertpoor, cream to whitish nodular limestones, passing upward to whitish porous plane-bedded limestones (chalks). Greenish clay interlayers occur, but are rare and thin (about $1 \mathrm{~cm}$ ): the succession is thus nearly completely carbonate.

\subsection{Pignola-Abriola section in the Lagonegro Basin}

The Carnian and Norian of the Lagonegro Basin (Fig. 1) are comprised of a thick succession of nodular limestones with chert nodules and beds, rich in radiolarian molds and thin-shelled bivalves mainly assignable to the genus Halobia (e.g., Scandone, 1967; Rigo et al., 2005, 2012a). Starting from the upper Norian (Sevatian) and continuing into the Rhaetian, the succession gradually becomes richer in shales and radiolarites through a ca. 30-40 m thick transitional interval (Amodeo, 1999; Passeri et al., 2005; Rigo et al., 2005, 2012a). The base of this transitional interval is marked by a ca. $3 \mathrm{~m}$ thick red shale horizon, dated to the late Norian Mockina bidentata conodont biochronozone (Rigo et 


\section{Location map}

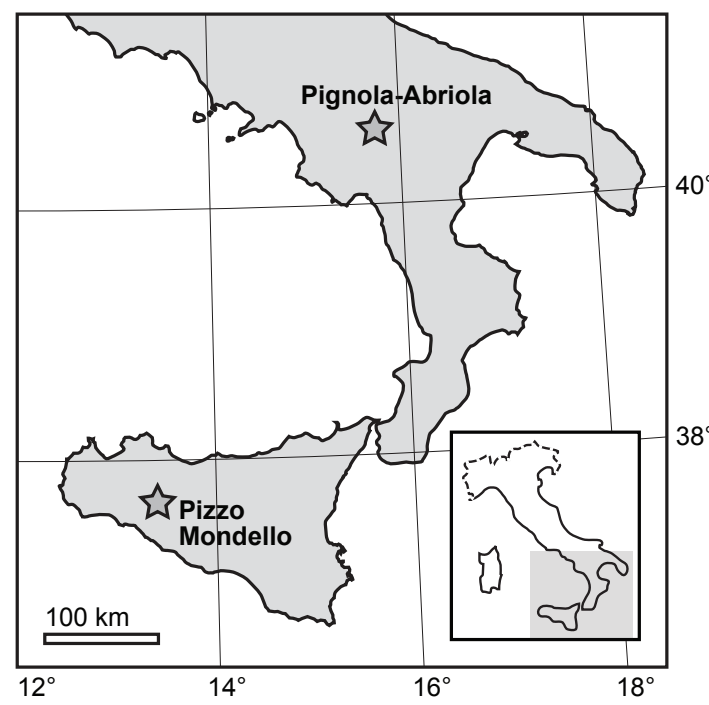

\section{Key for stratigraphic sections}

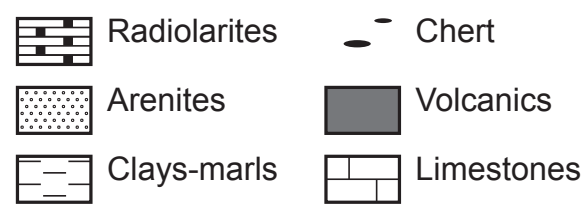

Lagonegro Basin (Pignola-Abriola)

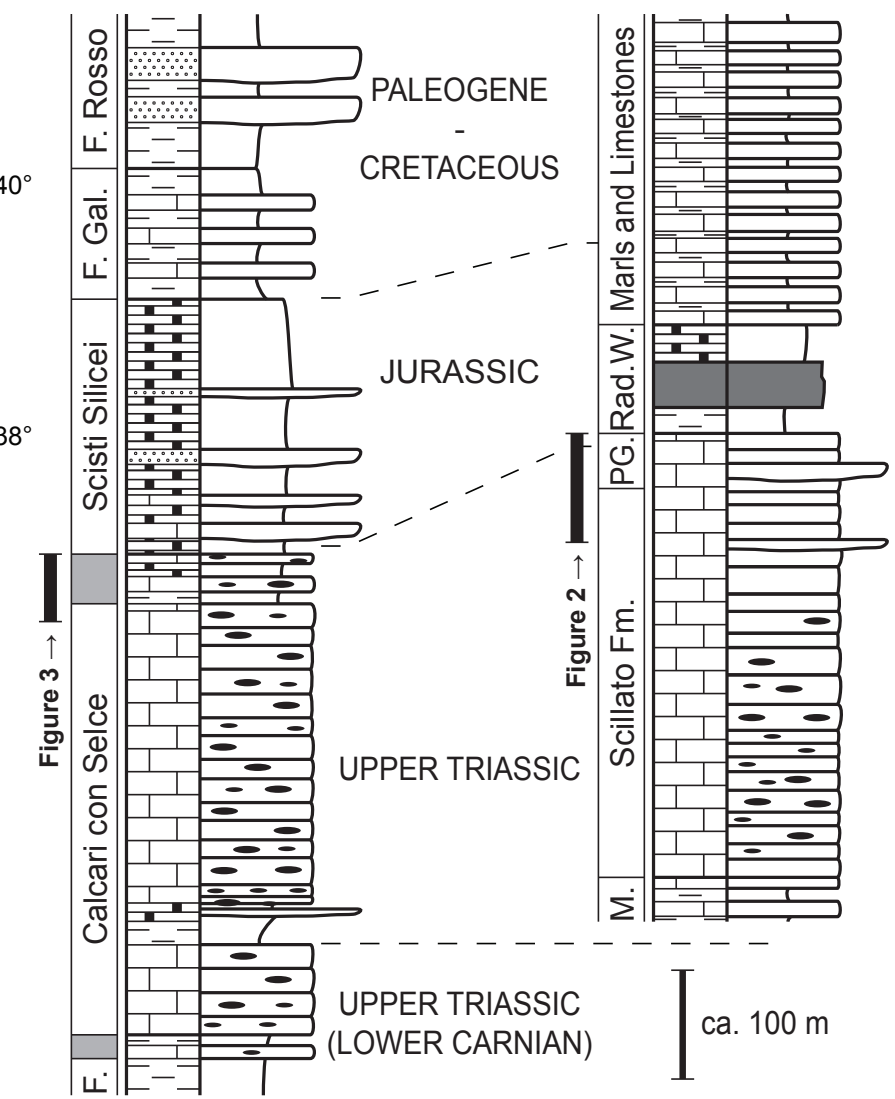

Fig. 1. Location of the studied stratigraphic sections in southern Italy, and synthetic stratigraphic succession of the Lagonegro Basin at Pignola (modified from Passeri et al., 2005) and of the Sicanian Basin at Pizzo Mondello (modified from Di Stefano et al., 1996). The scale is approximated.

al., 2005, 2012a). A radiolaritic succession of late Rhaetian to late Jurassic age follows. The transition from deep-water carbonate sedimentation to shale radiolarites that occurs basinwide in the late Norian-Rhaetian interval is interpreted as the deepening of the basin below the carbonate compensation depth (CCD) (e.g., Amodeo, 1999; Passeri et al., 2005; Giordano et al., 2011).

The studied succession at Pignola-Abriola (Fig. 3) encompasses most of the transitional interval above the basal red shale horizon, which is not documented, and the very base of the overlying shales and radiolarites. Conodont and radiolarian biostratigraphies constrain the succession to the late Norian-Rhaetian interval (Bazzucchi et al., 2005; Rigo et al., 2005, 2012a; Giordano et al., 2010).

\section{Materials and methods}

The proportion of Prinsiosphaera in the hemipelagic carbonates of this study was evaluated via point counting of SEM images. The use of thin sections was excluded, because Prinsiosphaera can break down into single elements (scales or calcite plates) about $1 \mu \mathrm{m}$ large that could not be seen under the optical microscope, not even in ultrathin sections (e.g., Erba and Tremolada, 2004). Methods for volume or flux estimation based on counts of individuals in a given area or volume (Young and Ziveri, 2000) are routinely applied for the volume estimation of nannofossils, especially if numerous taxa have to be distinguished, but modal analysis is the most adequate method for unbiased volume estimation of a single component in a consolidated rock (Chayes, 1951, 1954). Point counting provides an unbiased estimation under some assumptions that are commonly met in petrographic modal analysis: (a) point counting is performed on a surface, and (b) the sampling step is wider than the largest rock component (Van der Plas and Tobi, 1965).

Sixty-three samples of lime mudstone, silicified lime mudstone and intraclastic grainstone and breccia were prepared from Pignola-Abriola (Lagonegro Basin in the southern Apennines), while the 47 samples from Pizzo Mondello were 

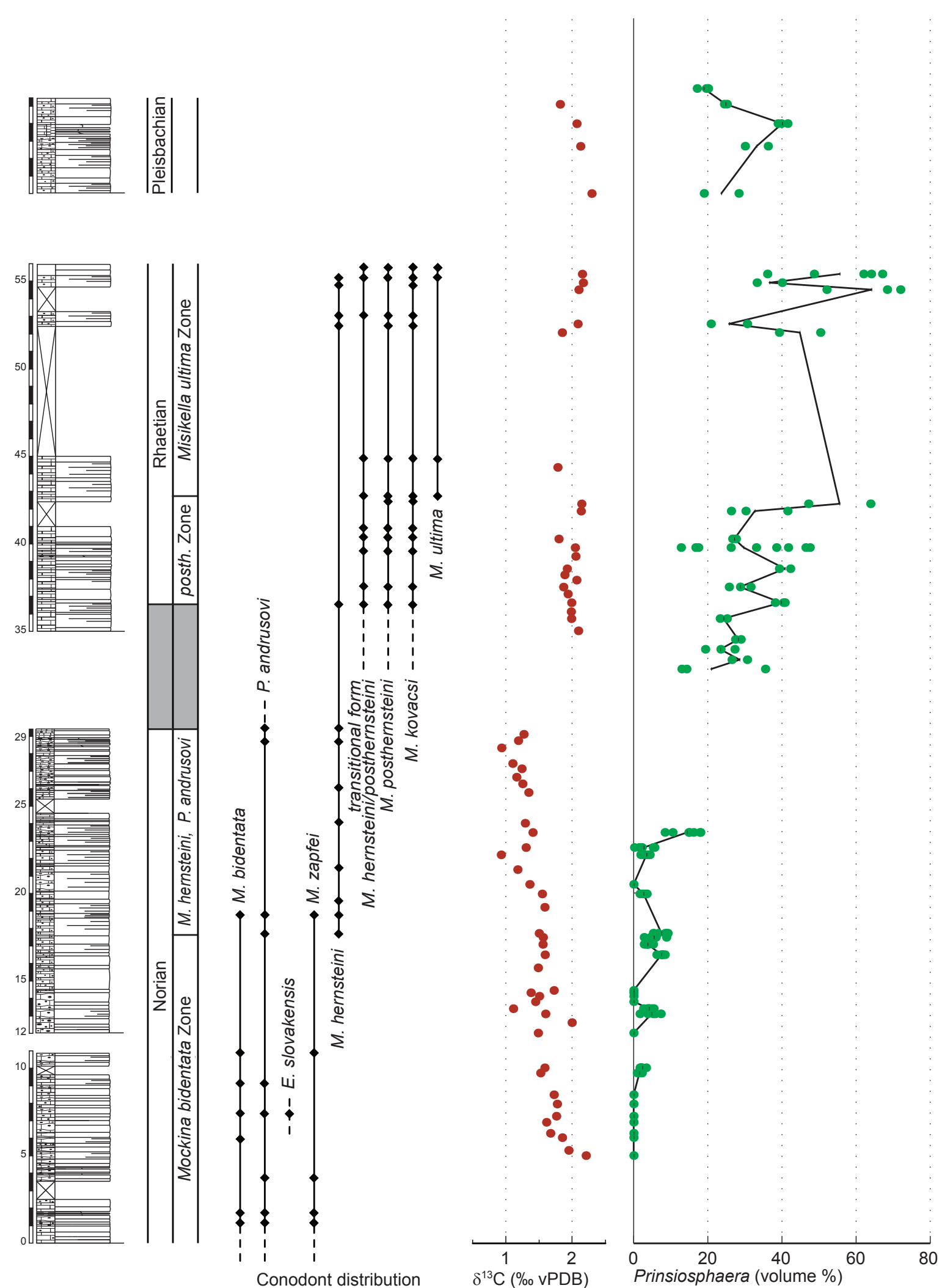

Fig. 2. Stratigraphy, stable carbon isotopes from bulk carbonate and volume proportion of calcareous nannofossils at Pizzo Mondello (Sicanian Basin, Sicily). The black line connects mean volume proportions of nannofossils. Biostratigraphy from Mazza et al. (2012) and Preto et al. (2012). Conodont biozones according to Kozur and Mock (1991). Lithological symbols as in Fig. 1. 

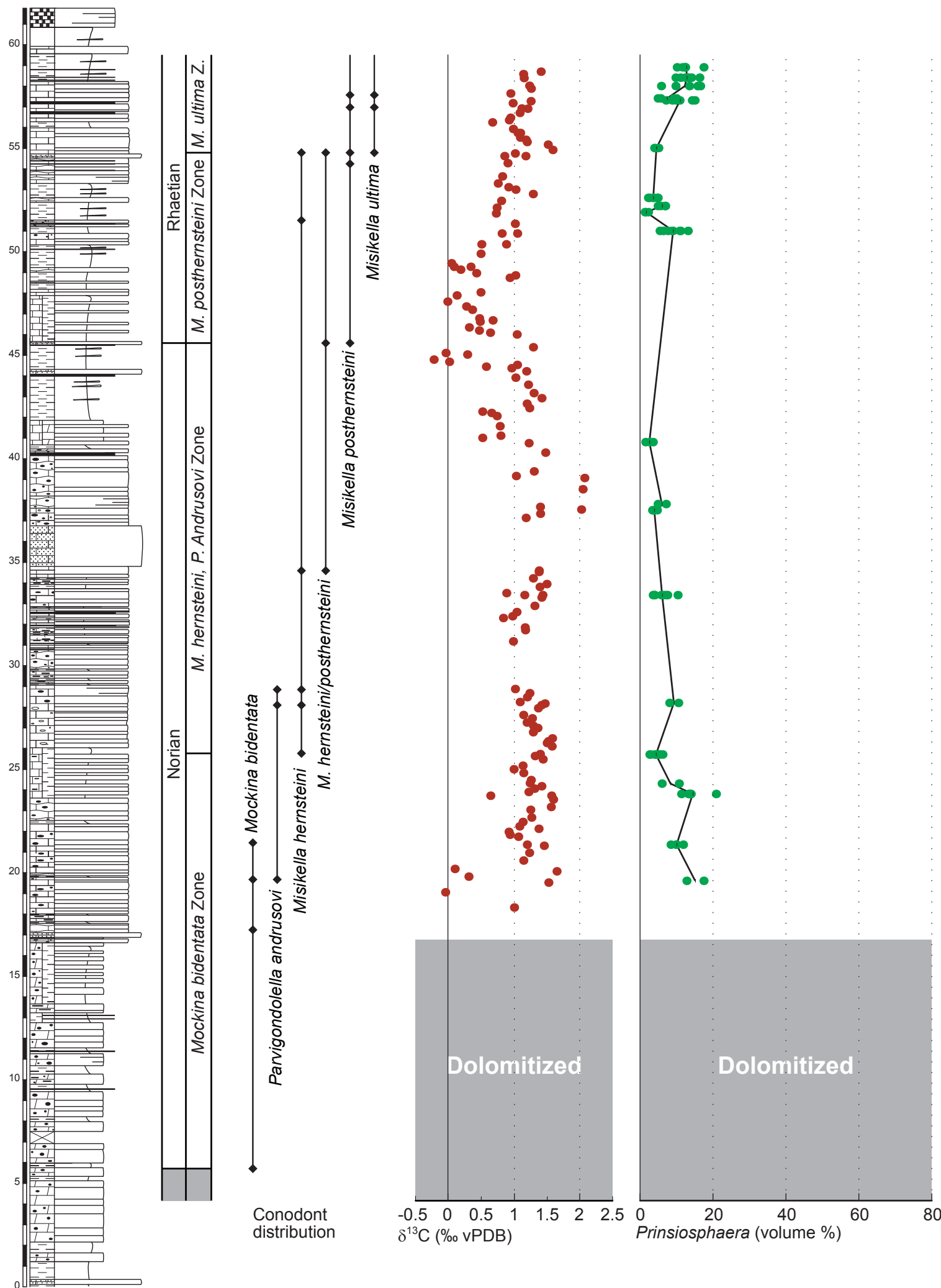

Fig. 3. Stratigraphy, stable carbon isotopes from bulk carbonate and volume proportion of calcareous nannofossils at Pignola-Abriola (Lagonegro Basin, southern Apennines, southern Italy). The black line connects mean volume proportions of nannofossils. Conodont distribution and biozones from Giordano et al. (2010). Conodont biozones according to Kozur and Mock (1991). Lithological symbols as in Fig. 1. 
all lime mudstone. Of the 63 samples from the Lagonegro Basin, only 20 were preserved well enough to allow for point counting. The most common diagenetic alteration that made impossible to perform significant point counting was silicification (Fig. 4).

All samples were cut in blocks of ca. $5 \mathrm{~mm} \times 5 \mathrm{~mm}$, polished with borcarbid powder (500 and then 800 mesh per inch), etched for $20-30 \mathrm{~s}$ in $0.3 \%$ hydrochloric acid, cleaned shortly in an ultrasonic bath, rinsed with deionized (Millipore) water, dried and gold coated. We analyzed surfaces perpendicular to bedding in order to minimize the effects of sample heterogeneity (Chayes, 1954). SEM images were taken at high magnification (ca. $2000 \times$ to $3000 \times$ and higher) with the Zeiss SUPRA 40 of the Department of Geosciences, University of Bremen. Etching was necessary to highlight crystal boundaries (Preto et al., 2013).

Point counting was performed by superimposing a regular grid of 28 columns and 19 rows (making up for 532 cross points) to SEM images (Fig. 5a-e). The grid spacing was chosen as to be larger than a single scale of Prinsiosphaera. A minimum of 2 up to 8 frames per sample were point counted, equaling 1064 to 4256 points counted per sample. This preparation ensured that estimations were made on a substantially flat surface. The point counting grid was designed in order to maintain two-sigma errors within less than $5 \%$, implying that $>400$ points per frame must be counted (Van der Plas and Toby, 1965). In a few cases, variability between frames of the same sample exceeded the error bounds (e.g., in sample at $39.75 \mathrm{~m}$ of Pizzo Mondello section, Fig. 2). This was attributed to sample heterogeneity (e.g., because of discontinuous bioturbation or preserved lamination).

Stable isotope analyses were performed on carbonate powders obtained with a dental drill from clean limestone surfaces, and carried out in two phases, first with Kiel- and Bremen-type Finnigan MAT mass spectrometers, reacting powders with $\mathrm{H}_{3} \mathrm{PO}_{4}$, at MARUM (University of Bremen), then by automated continuous-flow carbonate preparation GasBenchII device (Spötl and Vennemann, 2003) and ThermoElectron Delta Plus XP mass spectrometer at the IAMCCNR (Trapani, Italy) isotope geochemistry laboratory.

No systematic bias was recognized between samples from the same sections run in different laboratories. Care was taken to avoid late fractures, but it was impossible to separate calcareous nannofossils from their microsparitic matrix.

\section{Results}

\subsection{SEM petrology of nannofossil-bearing limestones}

The samples chosen for this study come from well-bedded lime mudstones and wackestones, with the exception of one sample from Pignola-Abriola, from a meter-scale calciturbidite bed. In this case, the ultrafacies and calcareous nannofossil abundance are referred to the reworked lime mudstone
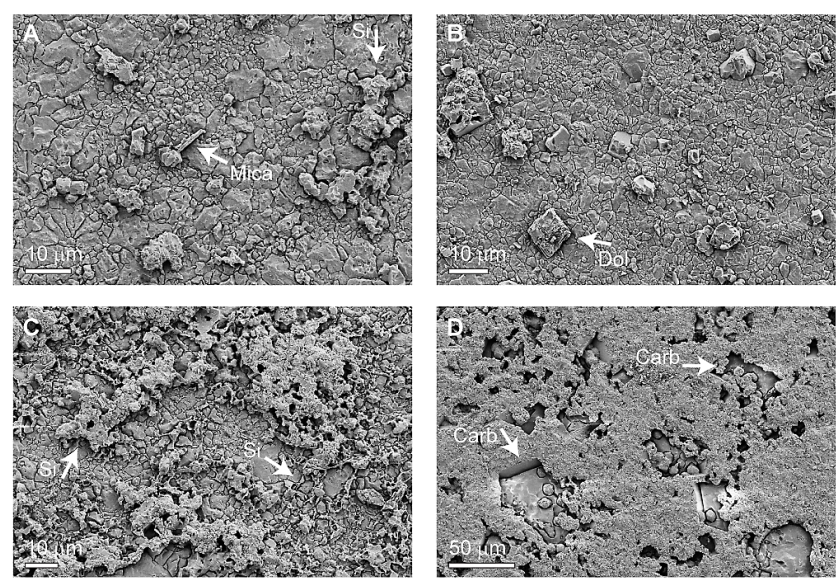

Fig. 4. Examples of diagenetic alteration of micrite and microsparite. (A) Slightly silicified sample with minor terrigenous component (mica crystal in the center of the frame). Calcareous nannofossils are easily visible. Silicified patches ( $\mathrm{Si}$ ) stick out of the sample plain because of etching. Pignola-Abriola section, Parvigondolella andrusovi-Misikella hernsteini conodont zone, late Norian, $33.3 \mathrm{~m}$ in Fig. 3. (B) Dolomite rhombohedrons (Dol) in microsparitic lime mudstone. Pignola-Abriola section, Misikella ultima conodont zone, Rhaetian, $58.8 \mathrm{~m}$ in Fig. 3. (C) Silicified lime mudstone. Silica $(\mathrm{Si})$ occupies a large part of the rock volume in this frame, and can be found in interstitial position between carbonate crystals or as patches. Pignola-Abriola section, Parvigondolella andrusovi-Misikella hernsteini conodont zone, late Norian, $40.7 \mathrm{~m}$ in Fig. 3. (D) Strongly silicified sample. Carbonate (Carb) is only present as a few crystals that partially engulf silica with spheroidal shape (chalcedony?). Locally, carbonate crystal faces are instead preserved. Pignola-Abriola section, Parvigondolella andrusovi-Misikella hernsteini conodont zone, late Norian, $45.1 \mathrm{~m}$ in Fig. 3.

lithoclasts that make up the coarse portion of the calciturbidite.

In all samples, carbonates are given by an admixture of relatively large (5-15 $\mu \mathrm{m}$ on average) pitted microspar crystals and small ( $1 \mu \mathrm{m}$ or less) platy calcite crystals (Figs. 5 and 6). The latter are interpreted as elements of the calcareous nannofossils Prinsiosphaera, which can break down in loose scales (Figs. 5c, g and 6a). Often, however, these micronscale platy calcite crystals or scales are still connected to form stacked groups of calcite plates and eventually spherical, solid nannoliths or "calcispheres" sensu lato assignable to Prinsiosphaera (Fig. 6).

Microspar crystals may vary in dimensions between samples, and are generally larger when Prinsiosphaera is scarce. In the Rhaetian samples of Pizzo Mondello, where calcareous nannofossils often reach $>50 \%$ of the rock volume, microspar crystals are mostly $<10 \mu \mathrm{m}$ in diameter (Fig. 5e). The preservation of complete specimens of Prinsiosphaera is, however, not related to the dimension of microspar crystals: complete "calcispheres" are in fact found irrespective of 

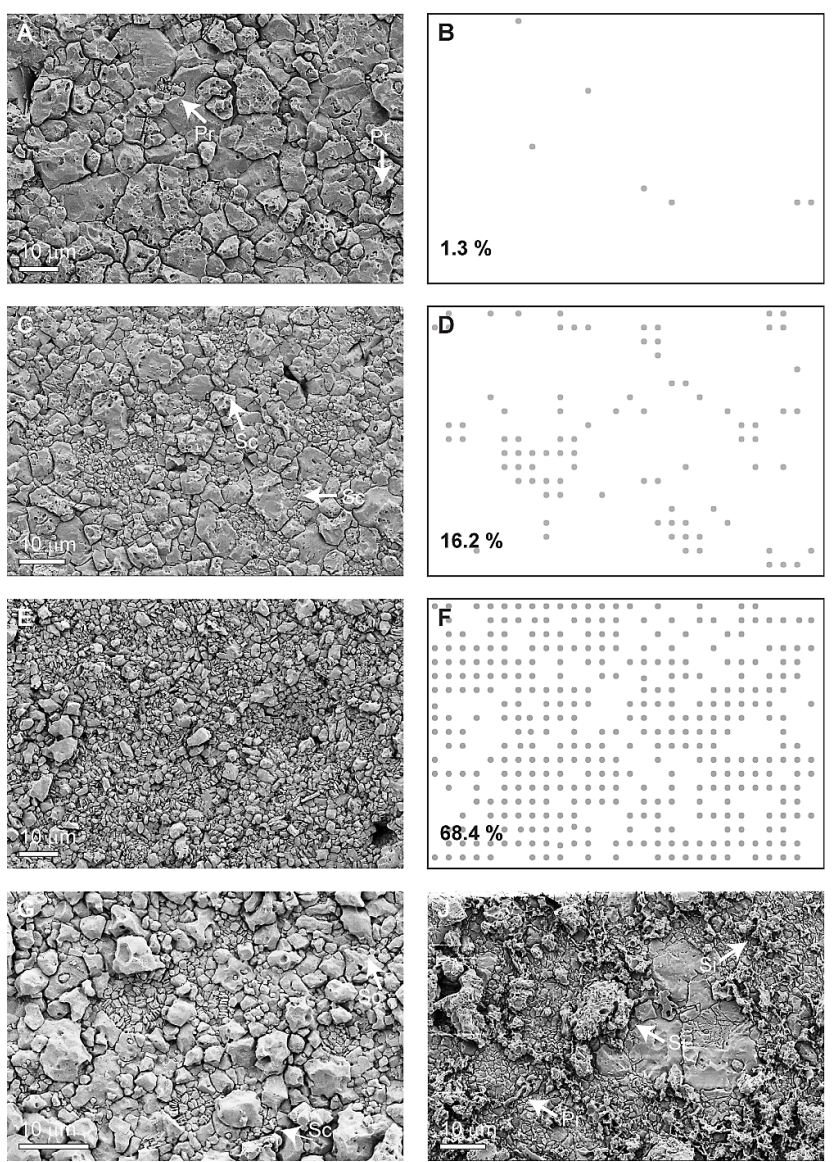

Fig. 5. Ultrafacies of late Norian and Rhaetian lime mudstones from Pignola-Abriola and Pizzo Mondello, as seen under the SEM. All samples of this figure were prepared with polishing and etching. In (A-E), SEM images are compared with the results of point counting. Three examples with scarce, abundant and dominant Prinsiosphaera are shown. (A) and (B) Sample from the Mockina bidentata conodont zone, late Norian of Pizzo Mondello, $9.71 \mathrm{~m}$ in Fig. 2. Note large microspar crystals with pits highlighted by etching. $\operatorname{Pr}=$ Prinsiosphaera . (C) and (D) Sample from the Parvigondolella andrusovi-Misikella hernsteini conodont zone, late Norian of Pizzo Mondello, $23.74 \mathrm{~m}$ in Fig. 2. In this sample, complete specimens of Prinsiosphaera are associated with isolated scales $(\mathrm{Sc})$ of disaggregated Prinsiosphaera "calcispheres". (E) and (F) Sample from the Misikella ultima conodont zone, Rhaetian of Pizzo Mondello, $54.5 \mathrm{~m}$ in Fig. 2. Prinsiosphaera is here the dominant rock component. Single specimens are compacted and indistinguishable. Note the fine microspar, with crystals always smaller than $10 \mu \mathrm{m}$. (G) Sample from the Mockina bidentata conodont zone, late Norian of Pignola-Abriola, $23.7 \mathrm{~m}$ in Fig. 3. Complete specimens of Prinsiosphaera with well-developed piles of scales are here associated with isolated scales (Sc), often engulfed by the surrounding microspar. (J) Sample from the Misikella posthernsteini conodont zone, Rhaetian of Pignola-Abriola, $52.1 \mathrm{~m}$ in Fig. 3. Silification formed in this sample's patches of amorphous silica or chert ( $\mathrm{Si}$ ) in interstitial positions that stick out of the sample surface after etching. The large, subrounded patch in the center may be a substituted radiolarian test. Prinsiosphaera (Pr) are still well recognizable and some microspar is also observed. their abundance or microspar crystal dimensions, and samples with abundant Prinsiosphaera and microspar $<10 \mu \mathrm{m}$ may be mostly formed by fragmented "calcispheres". Scales of broken Prinsiosphaera are often engulfed by microspar crystals (Fig. 5).

Isolated dolomite rhombohedrons may also occur in samples from both sections (Fig. 4), similar to those described by Bellanca et al. (1995). Dolomite only constitutes a minor component of the rock volume, and was only rarely framed in the SEM images used for volume estimation of calcareous nannofossils.

Silicification is common at Pignola-Abriola (Figs. 4, $5 \mathrm{j}$ and $6 \mathrm{~g}, \mathrm{j}$ ). Patches of amorphous silica or of unidentified silica minerals stick out on prepared SEM samples, because they are unaffected by etching. The proportion of sample that was silicified may vary from a few percent to nearly all the rock volume (Fig. 4). Generally, point counting was still possible with a proportion of silica up to ca. $25 \%$. Silica does not appear to substitute the small calcite crystals of Prinsiosphaera; instead, it occupies intracrystalline spaces. Spaces that are normally occupied by microspar in other samples may be taken over by silica in silicified samples (Fig. 4c and d).

\subsection{Calcareous nannofossils of the Sicanian and Lagonegro basins}

The dominant calcareous nannofossil in the two examined sections is by far Prinsiosphaera. Other calcareous nannofossil taxa such as thoracospherids (Fig. 6b) do not contribute substantially to hemipelagic carbonate sedimentation in the Triassic, while the Jurassic assemblages of Pizzo Mondello are fairly diverse (Preto et al., 2012).

Prinsiosphaera is a still enigmatic nannolith, whose features are strongly influenced by diagenetic alteration (Bralower et al., 1991). Its inner part is made of piles of micron-size scales that describe a full sphere. This inner part is the most easily preserved, it and was these micron-size scales that were recognized and point counted in this study (Fig. 6). Differently from older calcispheres that tend to develop an epitaxial overgrowth (Gardin et al., 2012; Preto et al., 2013), Prinsiosphaera is always easy to tell from the surrounding sediment. However, spheres were found to break down easily, and scales are thus often found disarticulated in a microspar matrix (Figs. 5c, g and 6a). Also in these cases, the distinction between scales of Prinsiosphaera and small crystals of the matrix is rarely equivocal, as epitaxial overgrowths never occur.

\subsection{Distribution of Prinsiosphaera}

The first Prinsiosphaera we documented at Pizzo Mondello is within the Mockina bidentata conodont zone, i.e., in the uppermost Norian (Fig. 2; Table 1). At Pignola-Abriola, the first Prinsiosphaera is observed immediately above a 

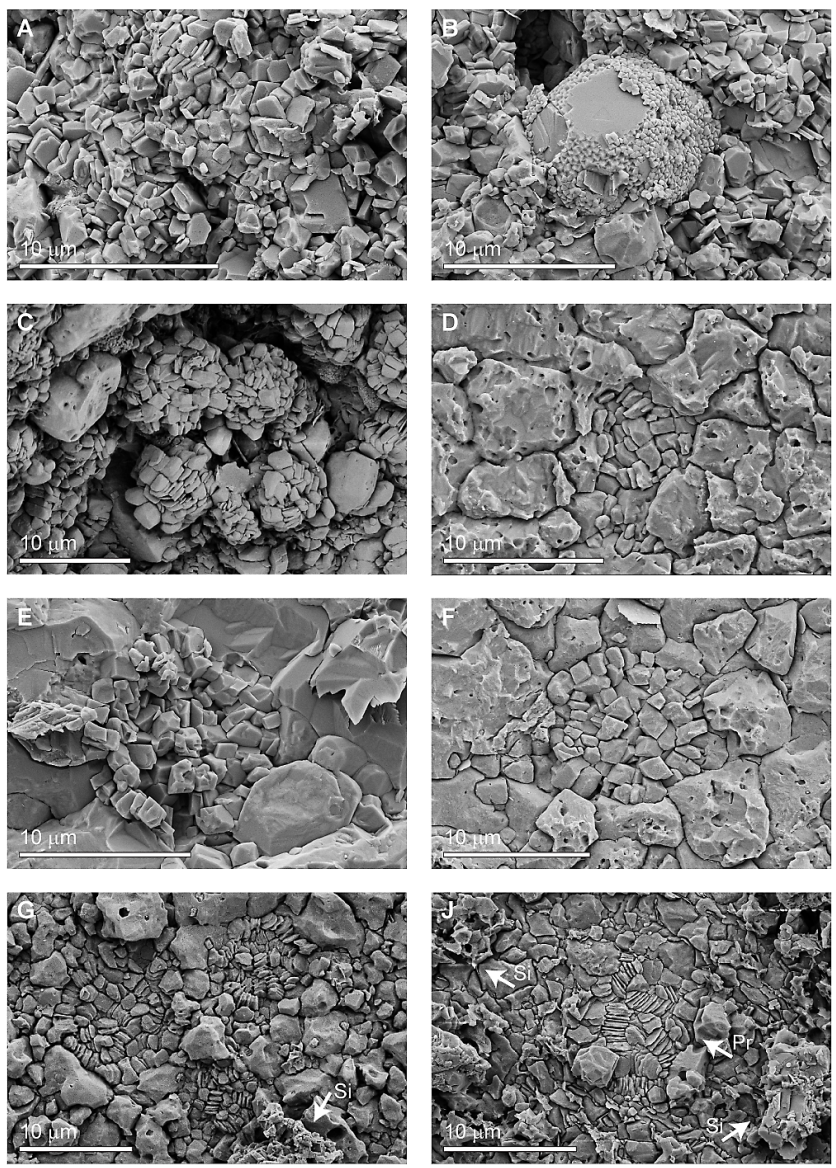

Fig. 6. Calcareous nannofossils from the late Norian and Rhaetian of the southern Apennines and Sicily. (A) Scales of Prinsiosphaera from the Misikella ultima conodont zone, Rhaetian of Pizzo Mondello, $54.5 \mathrm{~m}$ in Fig. 2: fresh broken sample. In this example, Prinsiosphaera "calcispheres" cannot be discerned either because they were disarticulated, or because they have been compacted during burial. (B) Thoracosphaera geometrica from the Misikella ultima conodont zone, Rhaetian of Pizzo Mondello, $54.5 \mathrm{~m}$ in Fig. 2: fresh broken sample. This and other nannofossils, different from Prinsiosphaera, are minor constituents of the carbonate sediment at Pizzo Mondello and were not recognized at Pignola-Abriola. (C) Prinsiosphaera from the Misikella posthernsteini conodont zone, Rhaetian of Pizzo Mondello, $40.25 \mathrm{~m}$ in Fig. 2: surface of "calcispheres" within a primary cavity of the sediment. (D) Prinsiosphaera from the Parvigondolella andrusovi-Misikella hernsteini conodont zone, late Norian of Pizzo Mondello, $19.95 \mathrm{~m}$ in Fig. 2: polished and etched sample. (E, F) Prinsiosphaera from the Mockina bidentata conodont zone, late Norian of Pizzo Mondello, $13.1 \mathrm{~m}$ in Fig. 2: comparison of the freshly broken sample (E) and polished and etched sample (F). (G) Three specimens of Prinsiosphaera with different diameters from the Mockina bidentata conodont zone, late Norian of Pignola-Abriola, $23.7 \mathrm{~m}$ in Fig. 3. This sample was polished and etched. Silicification ( $\mathrm{Si}$ ) is visible. (J) Prinsiosphaera (Pr) and silicified patches ( $\mathrm{Si}$ ) from the Misikella posthernsteini conodont zone, Rhaetian of Pignola-Abriola, $52.1 \mathrm{~m}$ in Fig. 3. Polished and etched sample. dolomitized interval present in the lower part of the succession within the upper Norian Mockina bidentata conodont zone (Fig. 3; Table 2).

Prinsiosphaera is overall more common at Pizzo Mondello, where its abundance in limestones reaches 50-60\% by the late Rhaetian in the Misikella ultima conodont zone. Because of the high proportion of calcareous nannofossils with respect to carbonate constituents of the rock and incomplete cementation, the Rhaetian limestones of Pizzo Mondello (Portella Gebbia limestone) are in fact chalks. The uppermost few meters of the Portella Gebbia limestone cropping out in the Pizzo Mondello section belong to the Lower Jurassic (Pliensbachian; Preto et al., 2012). These limestones contain abundant calcareous nannofossils, constituting ca. $20-40 \%$ of the rock volume.

At Pignola-Abriola, limestones are alternated to dominant shales, silicified claystones and cherts, and thus constitute only a minor part of the rock volume. Furthermore, the amount of carbonate produced by calcareous nannofossils is proportionally minor within limestones, ranging between 2.5 and $15 \%$ (Fig. 3; Table 2). A trend of increasing nannofossil abundance is again observed in the Rhaetian, within the Misikella ultima conodont zone, where Prinsiosphaera constitutes up to $12-13 \%$ of carbonate volume.

\subsection{Carbon isotope composition of carbonate}

The stable isotope composition of calcium carbonate (Tables 3 and 4) shows different values in the two analyzed sections, with a mean of $\delta^{13} \mathrm{C}=1.71 \pm 0.70 \%$, $\delta^{18} \mathrm{O}=-0.22 \pm 0.60 \%$ at Pizzo Mondello and $\delta^{13} \mathrm{C}=1.00 \pm 1.00 \%$, $\delta^{18} \mathrm{O}=-3.10 \pm 1.84 \%$ at PignolaAbriola. The stable isotope composition of samples from Pizzo Mondell is within the range of seawater $\delta^{13} \mathrm{C}$ estimated by Korte et al. (2005) for the Rhaetian (ca. 1 to $2.5 \%$ ), and in agreement with results of stable isotopic analyses on unaltered brachiopod shells from the Rhaetian of the Northern Calcareous Alps (Mette et al., 2012).

The $\delta^{13} \mathrm{C}$ and $\delta^{18} \mathrm{O}$ are strongly correlated at PignolaAbriola, while only a small and negative correlation coefficient is found at Pizzo Mondello (Fig. 7). A few samples from Pignola-Abriola come from a thick bed of coarse calciturbidite, and exhibit the highest $\delta^{13} \mathrm{C}$ values. All of these values are necessarily derived from bulk carbonate samples, which include both calcareous nannofossils and microspar. Contributions of minor carbonate components, as dolomite crystals or unidentified macrofossils, can be neglected on the basis of petrographic observations.

A decrease of the $\delta^{13} \mathrm{C}_{\text {carb }}$, reaching the absolute minimum value recorded in the Pignola-Abriola section, nearly corresponds to the Norian-Rhaetian boundary. This stratigraphic interval is not exposed at Pizzo Mondello, where, however, the lowest $\delta^{13} \mathrm{C}_{\text {carb }}$ values are recorded at about the $29 \mathrm{~m}$ level in the highest outcropping beds belonging to the Misikella hernsteini-Parvigondolella andrusovi 


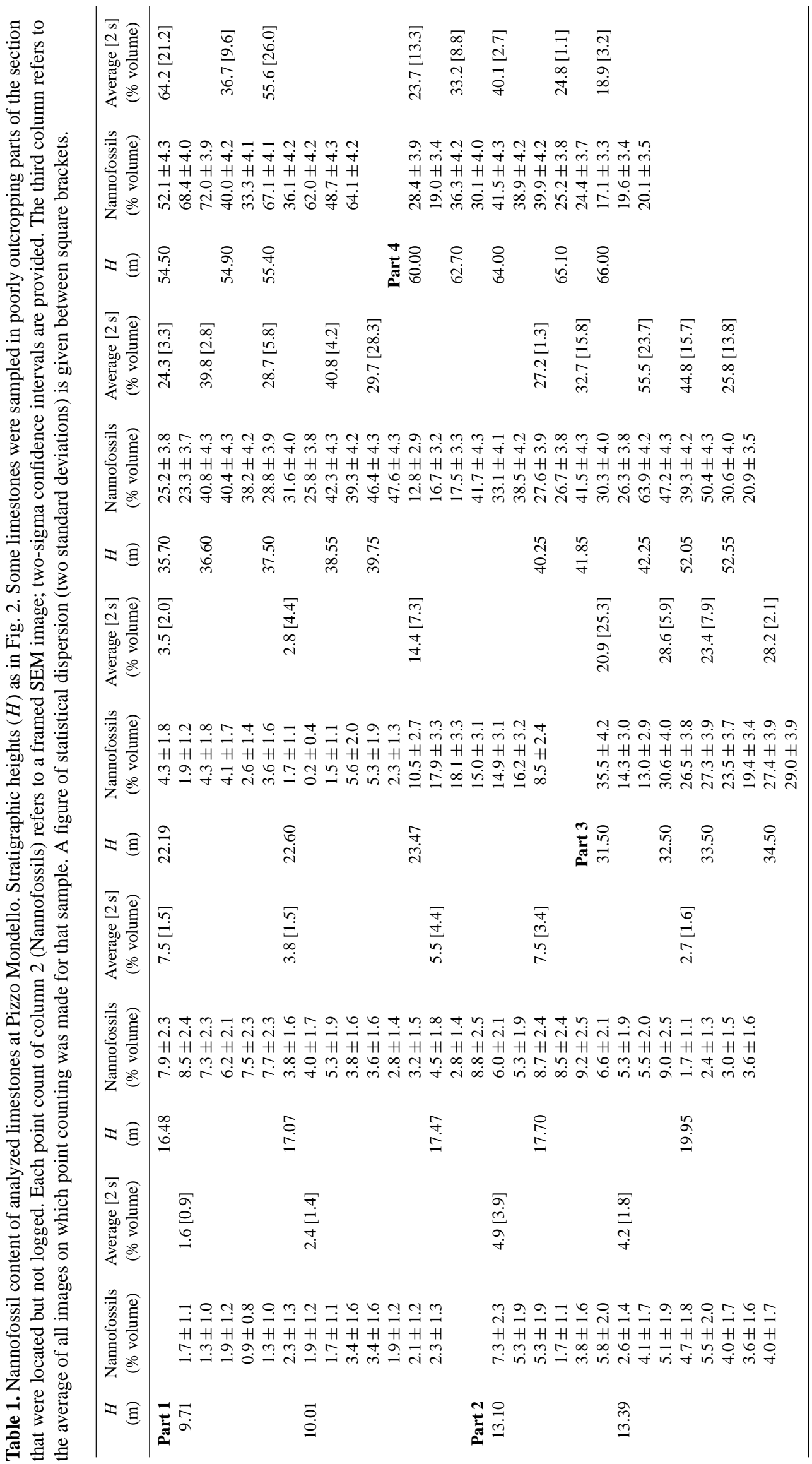


Table 2. Nannofossil content of analyzed limestones at Pignola-Abriola. Stratigraphic heights $(H)$ as in Fig. 3. Each point count of column 2 (Nannofossils) refers to a framed SEM image; two-sigma confidence intervals are provided. The third column refers to the average of all images on which point counting was made for that sample. A figure of statistical dispersion (two standard deviations) is given between square brackets.

\begin{tabular}{|c|c|c|c|c|c|c|c|c|c|c|c|}
\hline $\begin{array}{c}H \\
(\mathrm{~m})\end{array}$ & $\begin{array}{c}\text { Nannofossils } \\
\text { (\% volume) }\end{array}$ & $\begin{array}{c}\text { Average }[2 \mathrm{~s}] \\
(\% \text { volume })\end{array}$ & $\begin{array}{c}H \\
(\mathrm{~m})\end{array}$ & $\begin{array}{c}\text { Nannofossils } \\
\text { (\% volume) }\end{array}$ & $\begin{array}{c}\text { Average }[2 \mathrm{~s}] \\
(\% \text { volume })\end{array}$ & $\begin{array}{c}H \\
(\mathrm{~m})\end{array}$ & $\begin{array}{c}\text { Nannofossils } \\
\text { (\% volume) }\end{array}$ & $\begin{array}{r}\text { Average [2s] } \\
(\% \text { volume })\end{array}$ & $\begin{array}{c}H \\
(\mathrm{~m})\end{array}$ & $\begin{array}{c}\text { Nannofossils } \\
\text { (\% volume) }\end{array}$ & $\begin{array}{c}\text { Average }[2 \mathrm{~s}] \\
\text { (\% volume) }\end{array}$ \\
\hline \multirow[t]{2}{*}{19.50} & $17.5 \pm 3.3$ & $15.1[6.6]$ & 33.30 & $4.0 \pm 1.7$ & $6.1[4.6]$ & 51.80 & $2.3 \pm 1.3$ & $1.7[1.0]$ & 57.90 & $9.8 \pm 2.6$ & 12.3 [8.9] \\
\hline & $12.8 \pm 2.9$ & & & $7.5 \pm 2.3$ & & & $1.5 \pm 1.1$ & & & $15.8 \pm 3.2$ & \\
\hline \multirow[t]{5}{*}{21.25} & $8.5 \pm 2.4$ & $10.0[2.4]$ & & $4.0 \pm 1.7$ & & & $1.3 \pm 1.0$ & & & $16.5 \pm 3.2$ & \\
\hline & $9.9 \pm 2.6$ & & & $5.8 \pm 2.0$ & & 52.10 & $5.6 \pm 2.0$ & 6.1 [1.9] & & $5.8 \pm 2.0$ & \\
\hline & $9.9 \pm 2.6$ & & & $6.4 \pm 2.1$ & & & $6.8 \pm 2.2$ & & & $13.5 \pm 3.0$ & \\
\hline & $10.0 \pm 2.6$ & & & $3.6 \pm 1.6$ & & & $4.9 \pm 1.9$ & & 58.30 & $12.8 \pm 2.9$ & $12.8[4.2]$ \\
\hline & $11.8 \pm 2.8$ & & & $7.1 \pm 2.2$ & & & $7.0 \pm 2.2$ & & & $14.1 \pm 3.0$ & \\
\hline \multirow[t]{6}{*}{23.70} & $13.5 \pm 3.0$ & $14.4[6.6]$ & & $10.3 \pm 2.6$ & & 52.50 & $2.3 \pm 1.3$ & $3.6[2.1]$ & & $16.4 \pm 3.2$ & \\
\hline & $20.9 \pm 3.5$ & & 37.40 & $3.6 \pm 1.6$ & 3.9 [1.2] & & $3.6 \pm 1.6$ & & & $9.8 \pm 2.6$ & \\
\hline & $13.7 \pm 3.0$ & & & $4.0 \pm 1.7$ & & & $3.8 \pm 1.6$ & & & $13.4 \pm 2.9$ & \\
\hline & $14.0 \pm 3.0$ & & & $4.7 \pm 1.8$ & & & $2.6 \pm 1.4$ & & & $11.1 \pm 2.7$ & \\
\hline & $13.3 \pm 2.9$ & & & $3.4 \pm 1.6$ & & & $4.7 \pm 1.8$ & & & $12.4 \pm 2.9$ & \\
\hline & $11.3 \pm 2.7$ & & 37.70 & $4.9 \pm 1.9$ & $6.0[3.2]$ & & $4.9 \pm 1.9$ & & 58.80 & $12.4 \pm 2.9$ & $12.7[5.0]$ \\
\hline \multirow[t]{2}{*}{24.20} & $6.0 \pm 2.1$ & $8.4[6.6]$ & & $7.1 \pm 2.2$ & & 54.90 & $4.0 \pm 1.7$ & 4.5 [1.6] & & $17.5 \pm 3.3$ & \\
\hline & $10.7 \pm 2.7$ & & 40.70 & $1.5 \pm 1.1$ & 2.6 [1.7] & & $5.1 \pm 1.9$ & & & $11.7 \pm 2.8$ & \\
\hline \multirow[t]{8}{*}{25.60} & $5.5 \pm 2.0$ & $4.4[2.4]$ & & $3.6 \pm 1.6$ & & 57.20 & $15.0 \pm 3.1$ & 11.0 [6.2] & & $12.2 \pm 2.8$ & \\
\hline & $2.8 \pm 1.4$ & & & $2.6 \pm 1.4$ & & & $7.1 \pm 2.2$ & & & $10.2 \pm 2.6$ & \\
\hline & $4.9 \pm 1.9$ & & & $2.6 \pm 1.4$ & & & $10.9 \pm 2.7$ & & & $12.4 \pm 2.9$ & \\
\hline & $4.3 \pm 1.8$ & & 50.90 & $6.4 \pm 2.1$ & $9.1[5.1]$ & & $8.8 \pm 2.5$ & & & & \\
\hline & $4.7 \pm 1.8$ & & & $5.5 \pm 2.0$ & & & $9.8 \pm 2.6$ & & & & \\
\hline & $6.2 \pm 2.1$ & & & $8.8 \pm 2.5$ & & & $14.3 \pm 3.0$ & & & & \\
\hline & $4.0 \pm 1.7$ & & & $7.7 \pm 2.3$ & & 57.30 & $4.9 \pm 1.9$ & $7.4[5.1]$ & & & \\
\hline & $2.6 \pm 1.4$ & & & $10.9 \pm 2.7$ & & & $5.6 \pm 2.0$ & & & & \\
\hline \multirow[t]{3}{*}{28.10} & $8.1 \pm 2.4$ & $9.3[3.5]$ & & $9.0 \pm 2.5$ & & & $10.0 \pm 2.6$ & & & & \\
\hline & $10.5 \pm 2.7$ & & & $11.1 \pm 2.7$ & & & $9.2 \pm 2.5$ & & & & \\
\hline & & & & $13.2 \pm 2.9$ & & & & & & & \\
\hline
\end{tabular}
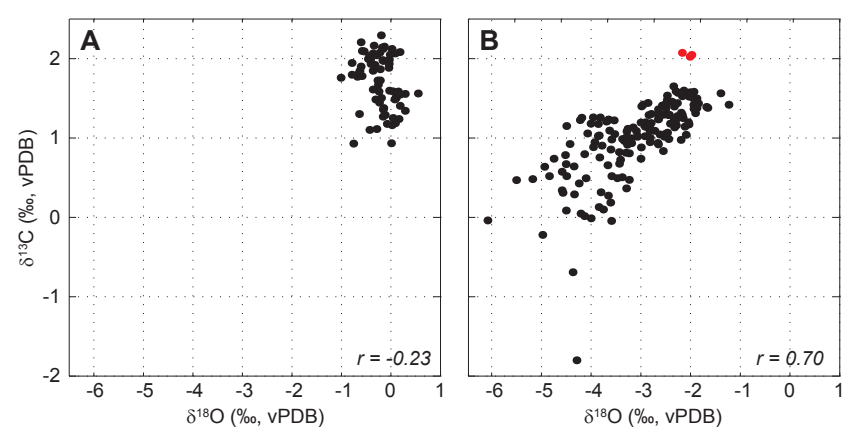

Fig. 7. Crossplots of stable isotope analyses of bulk carbonate from (A) Pizzo Mondello and (B) Pignola-Abriola. The samples marked in red are from a thick calciturbidite in the uppermost Norian portion of the Pignola-Abriola section. Correlation coefficients $(r)$ are both significantly different from zero at the $95 \%$ level.

conodont zone (the youngest of the Norian). The base of the Rhaetian is thus generally associated with a rising trend of the $\delta^{13} \mathrm{C}_{\text {carb }}$ values, which is best recorded at PignolaAbriola. Interestingly, the contribution of calcareous nannofossils to carbonate production is also rising during the basal part of the Rhaetian in both sections (Fig. 2). More specifically, $\delta^{13} \mathrm{C}_{\text {carb }}$ was found to be positively correlated with the content of calcareous nannofossils in both sections (Fig. 8).

\section{Discussion}

\subsection{Contribution of calcareous nannofossils to hemipelagic carbonate sedimentation in western Tethys}

In our Triassic samples, nearly all calcareous nannofossils are assignable to Prinsiosphaera. The volume contribution of calcareous nannofossils becomes detectable starting from the upper Norian portion of the Pizzo Mondello section, within the Sevatian substage, a few meters below the last occurrence of the conodont Mockina bidentata and the first occurrence of Misikella hernsteini. The methods used in this study are not easily comparable to standard calcareous nannofossil counts of biostratigraphic investigations, which consist of semiquantitative counting performed on smear slides. However, our data are roughly in agreement with the first abundant occurrence of nannoliths and coccoliths in Tethys in the late Norian according to Gardin et al. (2012). This horizon is included at Pignola-Abriola within the basal interval affected by dolomitization, and the first samples analyzed already contain a rather high proportion of nannofossils, $>10 \%$.

Afterwards, the volume proportion of calcareous nannofossils increases, reaching $64 \%$ by the late Rhaetian at Pizzo Mondello. In this locality, probably due to the high content 
Table 3. Stable isotope composition of oxygen and carbon in limestones of the Pizzo Mondello section. Stratigraphic heights $(H)$ as in Fig. 2.

\begin{tabular}{rrrrrrrrr}
\hline$H(\mathrm{~m})$ & $\delta^{18} \mathrm{O}$ & $\delta^{13} \mathrm{C}$ & $H(\mathrm{~m})$ & $\delta^{18} \mathrm{O}$ & $\delta^{13} \mathrm{C}$ & $H(\mathrm{~m})$ & $\delta^{18} \mathrm{O}$ & $\delta^{13} \mathrm{C}$ \\
\hline Part 1 & & & 17.47 & 0.54 & 1.56 & 37.10 & -0.41 & 1.93 \\
5.00 & -0.61 & 2.21 & 17.70 & 0.10 & 1.50 & 37.50 & -0.22 & 1.87 \\
5.30 & -0.79 & 1.95 & 19.20 & 0.14 & 1.59 & 37.90 & 0.08 & 2.07 \\
6.02 & -0.64 & 1.85 & 19.95 & 0.18 & 1.55 & 38.20 & -0.05 & 1.88 \\
6.27 & -0.26 & 1.67 & 20.50 & -0.16 & 1.36 & 38.55 & -0.33 & 1.92 \\
6.90 & -0.37 & 1.61 & 21.35 & -0.09 & 1.18 & 39.25 & -0.02 & 2.05 \\
7.25 & -1.02 & 1.76 & 22.19 & -0.76 & 0.93 & 39.75 & -0.30 & 2.04 \\
7.95 & -0.68 & 1.77 & 22.60 & -0.64 & 1.30 & 40.25 & -0.79 & 1.80 \\
8.47 & -0.27 & 1.72 & 23.47 & 0.18 & 1.41 & 41.85 & -0.16 & 2.13 \\
9.71 & 0.10 & 1.52 & 24.00 & -0.12 & 1.29 & 42.25 & -0.18 & 2.14 \\
10.01 & -0.25 & 1.59 & 25.76 & 0.28 & 1.34 & 44.35 & -0.59 & 1.78 \\
& & & 26.26 & 0.04 & 1.25 & 52.05 & -0.37 & 1.85 \\
Part 2 & & & 26.63 & 0.02 & 1.16 & 52.55 & 0.17 & 2.08 \\
12.00 & 0.07 & 1.49 & 27.11 & 0.15 & 1.24 & 54.50 & -0.59 & 2.10 \\
12.60 & -0.47 & 2.00 & 27.41 & -0.44 & 1.10 & 54.90 & -0.35 & 2.16 \\
13.10 & -0.04 & 1.60 & 28.30 & 0.00 & 0.93 & 55.40 & -0.14 & 2.15 \\
13.39 & -0.29 & 1.11 & 28.72 & 0.08 & 1.19 & & & \\
13.80 & -0.24 & 1.45 & 29.08 & -0.16 & 1.27 & Part 4 & & \\
14.10 & -0.20 & 1.50 & & & & 60.00 & -0.20 & 2.29 \\
14.30 & -0.15 & 1.38 & Part 3 & & & 62.70 & 0.01 & 2.12 \\
14.44 & -0.22 & 1.72 & 35.00 & -0.55 & 2.09 & 64.00 & -0.37 & 2.07 \\
15.73 & -0.31 & 1.49 & 35.70 & -0.04 & 1.99 & 65.10 & -0.66 & 1.82 \\
16.48 & 0.03 & 1.59 & 36.10 & -0.17 & 1.98 & & & \\
17.07 & 0.28 & 1.56 & 36.60 & -0.42 & 1.99 & & & \\
\hline
\end{tabular}

of low-Mg calcite nannofossils and consequent paucity of metastable carbonate that could reprecipitate as microspar cement during diagenesis, upper Rhaetian and Jurassic lime mudstones retained high microporosity, and are thus true chalk. The highest nannofossil abundances are reached in the late Rhaetian. Five Jurassic (Pliensbachian) samples show lower average volume contribution by calcareous nannofossils of $28 \%$.

It is interesting to compare the contribution of Prinsiosphaera in the two localities, keeping in mind that the facies of Pizzo Mondello are overall closer to a coastline, and probably shallower, than those of Pignola-Abriola (Rigo et al., 2012b). The Lagonegro Basin fell below the CCD near the Triassic-Jurassic boundary, while Pizzo Mondello always remained above it. At Pignola-Abriola, the passage below the CCD is documented at the base of Jurassic radiolarites of the Scisti Silicei formation, at the top of the Pignola-Abriola section.

Prinsiosphaera is the dominant component of upper Rhaetian sediments at Pizzo Mondello but remains only a minor contributor in the more distal Pignola-Abriola section (Fig. 9). Moreover, the limestone beds are diluted by a high proportion of siliceous and clay beds at Pignola-Abriola, while the coeval succession of Pizzo Mondello is practically all limestone. We could not detect any obvious difference in preservation of nannofossils between the two localities. Specimens of Prinsiosphaera are always preserved as full
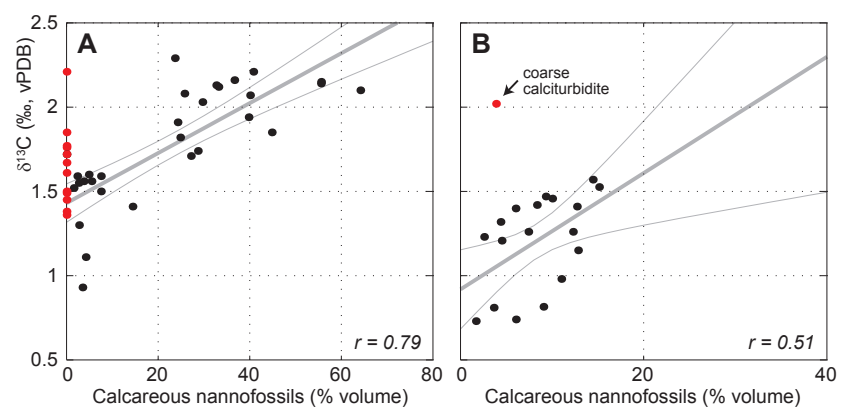

Fig. 8. Carbon isotope composition $\left(\delta^{13} \mathrm{C}\right)$ of lime mudstone plotted against the abundance of calcareous nannofossils at Pizzo Mondello (A) and Pignola-Abriola (B). The $\delta^{13} \mathrm{C}$ is clearly correlated with nannofossil abundance (see correlation coefficients $(r)$ ) which are both significantly different from zero at the $95 \%$ level. Linear fit is plotted with $90 \%$ error bounds. Twelve samples of Pizzo Mondello without nannofossils and one sample of Pignola from a $2 \mathrm{~m}$ thick coarse calciturbidite are marked in red and were excluded from computation.

spheres or isolated scales, but, for instance, there is no sign of a reduction of the volume of spheres due to dissolution. We thus assume that the difference in abundance between the two sections reflects a different original abundance of this nannolith. Prinsiosphaera was apparently more common in 
Table 4. Stable isotope composition of oxygen and carbon in limestones of the Pizzo Mondello section. Stratigraphic heights $(H)$ as in Fig. 3.

\begin{tabular}{|c|c|c|c|c|c|c|c|c|c|c|c|}
\hline$H(\mathrm{~m})$ & $\delta^{18} \mathrm{O}$ & $\delta^{13} \mathrm{C}$ & $H(\mathrm{~m})$ & $\delta^{18} \mathrm{O}$ & $\delta^{13} \mathrm{C}$ & $H(\mathrm{~m})$ & $\delta^{18} \mathrm{O}$ & $\delta^{13} \mathrm{C}$ & $H(\mathrm{~m})$ & $\delta^{18} \mathrm{O}$ & $\delta^{13} \mathrm{C}$ \\
\hline 18.31 & -2.82 & 1.00 & 27.09 & -2.56 & 1.29 & 42.06 & -4.75 & 0.74 & 50.35 & -3.38 & 0.51 \\
\hline 19.06 & -3.60 & -0.05 & 27.26 & -3.01 & 1.19 & 42.21 & -3.67 & 0.66 & 50.88 & -2.52 & 1.05 \\
\hline 19.32 & -4.29 & -1.80 & 27.46 & -2.27 & 1.28 & 42.27 & -4.50 & 0.52 & 50.88 & -3.31 & 0.81 \\
\hline 19.52 & -2.17 & 1.53 & 27.62 & -2.12 & 1.14 & 42.44 & -2.66 & 1.23 & 51.35 & -3.08 & 1.02 \\
\hline 19.81 & -4.57 & 0.31 & 27.95 & -1.94 & 1.37 & 42.65 & -2.35 & 1.20 & 51.85 & -3.42 & 0.73 \\
\hline 20.06 & -2.35 & 1.65 & 28.10 & -1.94 & 1.42 & 42.93 & -2.96 & 1.42 & 52.13 & -3.00 & 0.74 \\
\hline 20.18 & -3.76 & 0.10 & 28.17 & -1.90 & 1.47 & 43.17 & -2.66 & 1.30 & 52.45 & -3.24 & 0.81 \\
\hline 20.59 & -2.87 & 1.14 & 28.24 & -2.72 & 1.09 & 43.57 & -3.68 & 1.22 & 52.78 & -2.46 & 1.29 \\
\hline 20.96 & -2.30 & 1.23 & 28.48 & -2.32 & 1.20 & 43.91 & -3.86 & 1.02 & 53.00 & -3.08 & 1.03 \\
\hline 21.30 & -2.38 & 1.46 & 28.67 & -2.34 & 1.24 & 44.22 & -2.80 & 1.19 & 53.11 & -3.28 & 0.92 \\
\hline 21.36 & -2.05 & 1.20 & 28.87 & -2.54 & 1.02 & 44.37 & -3.34 & 0.96 & 53.30 & -3.83 & 0.76 \\
\hline 21.74 & -2.47 & 1.07 & 31.18 & -2.44 & 0.99 & 44.44 & -4.59 & 0.58 & 53.64 & -3.44 & 0.82 \\
\hline 21.83 & -2.67 & 0.94 & 31.71 & -2.04 & 1.17 & 44.53 & -3.53 & 1.05 & 54.28 & -3.79 & 0.90 \\
\hline 21.98 & -2.66 & 0.92 & 31.84 & -2.31 & 1.17 & 44.68 & -4.14 & 0.02 & 54.61 & -3.86 & 1.18 \\
\hline 22.12 & -2.50 & 1.38 & 32.30 & -2.56 & 0.84 & 44.79 & -4.98 & -0.22 & 54.61 & -3.61 & 0.86 \\
\hline 22.24 & -3.29 & 1.08 & 32.39 & -2.20 & 0.98 & 45.03 & -4.34 & 0.29 & 54.75 & -3.29 & 1.02 \\
\hline 22.45 & -2.33 & 1.13 & 32.59 & -2.10 & 1.04 & 45.10 & -6.09 & -0.04 & 54.92 & -2.30 & 1.59 \\
\hline 22.66 & -2.22 & 1.27 & 32.88 & -1.91 & 1.31 & 45.38 & -2.43 & 1.29 & 55.17 & -1.97 & 1.52 \\
\hline 23.03 & -2.16 & 1.25 & 33.30 & -1.24 & 1.42 & 46.00 & -2.62 & 1.04 & 55.30 & -2.91 & 1.20 \\
\hline 23.17 & -1.40 & 1.56 & 33.42 & -2.29 & 1.16 & 46.09 & -4.94 & 0.64 & 55.40 & -4.01 & 1.18 \\
\hline 23.54 & -2.14 & 1.60 & 33.51 & -3.96 & 0.88 & 46.19 & -5.51 & 0.47 & 55.51 & -3.63 & 1.09 \\
\hline 23.72 & -4.35 & 0.64 & & -1.85 & 1.44 & & -4.37 & -0.69 & & -4.08 & 1.06 \\
\hline 23.72 & -2.26 & 1.57 & 33.94 & -1.88 & 1.50 & 46.34 & -3.81 & 0.32 & 55.73 & -2.83 & 1.10 \\
\hline 23.90 & -3.54 & 1.22 & 33.80 & -1.69 & 1.39 & 46.61 & -5.18 & 0.48 & 55.93 & -3.38 & 0.99 \\
\hline 24.06 & -2.50 & 1.31 & 34.22 & -2.17 & 1.29 & 46.68 & -3.44 & 0.68 & 56.25 & -4.51 & 0.67 \\
\hline 24.17 & -2.53 & 1.42 & 34.53 & -1.88 & 1.38 & 46.77 & -3.24 & 0.47 & 56.35 & -4.43 & 0.92 \\
\hline 24.32 & -2.65 & 1.24 & 34.60 & -1.66 & 1.38 & 47.19 & -3.30 & 0.36 & 56.47 & -3.93 & 0.95 \\
\hline 24.47 & -3.82 & 1.26 & 37.13 & -2.41 & 1.18 & 47.35 & -3.66 & 0.27 & 56.71 & -3.10 & 1.09 \\
\hline 24.82 & -2.83 & 1.14 & 37.34 & -2.51 & 1.40 & 47.59 & -4.01 & -0.01 & 56.90 & -3.70 & 1.21 \\
\hline 25.00 & -3.20 & 1.00 & 37.55 & -2.02 & 2.02 & 47.88 & -3.85 & 0.13 & 56.92 & -3.27 & 1.12 \\
\hline 25.17 & -3.16 & 1.13 & 37.67 & -2.99 & 1.40 & 48.03 & -4.11 & 0.49 & 57.17 & -3.59 & 0.98 \\
\hline 25.48 & -2.27 & 1.44 & 38.53 & -1.98 & 2.05 & 48.73 & -3.19 & 0.94 & 57.27 & -4.19 & 1.26 \\
\hline 25.64 & -2.19 & 1.32 & 39.07 & -2.17 & 2.07 & 48.86 & -2.92 & 1.02 & 57.64 & -2.82 & 0.95 \\
\hline 25.73 & -2.33 & 1.40 & 39.16 & -3.85 & 1.03 & 48.96 & -4.25 & 0.43 & 57.87 & -3.96 & 1.26 \\
\hline 26.10 & -2.02 & 1.58 & 39.38 & -2.80 & 1.30 & 49.13 & -3.61 & 0.19 & 58.02 & -3.66 & 1.23 \\
\hline 26.27 & -1.96 & 1.50 & 40.29 & -2.48 & 1.48 & 49.26 & -4.59 & 0.34 & 58.39 & -4.50 & 1.15 \\
\hline 26.34 & -2.04 & 1.52 & 40.75 & -4.22 & 1.23 & 49.26 & -4.51 & 0.09 & 58.57 & -2.92 & 1.14 \\
\hline 26.49 & -1.94 & 1.58 & 41.01 & -4.85 & 0.52 & 49.44 & -4.21 & 0.05 & 58.70 & -2.58 & 1.41 \\
\hline 26.78 & -2.85 & 1.29 & 41.11 & -4.14 & 0.80 & 49.90 & -3.48 & 0.49 & & & \\
\hline 26.99 & -2.65 & 1.36 & 41.57 & -4.52 & 0.79 & 50.35 & -3.00 & 0.88 & & & \\
\hline
\end{tabular}

the shallower (proximal) periplatform basins of Sicily than in the more open marine setting of the Lagonegro Basin.

The main observation is, however, that calcareous nannofossils were a primary component of hemipelagic (or pelagic) carbonates during the latest Triassic. At that time, Prinsiosphaera must have played already a role in stabilizing the carbon cycle and thus in triggering the transition from a "Neritan" to a "Cretan" ocean (Zeebe and Westbroeck, 2003). The success of Prinsiosphaera as planktonic carbonate producer was, however, ephemeral: the Triassic/Jurassic mass extinction severely hit marine carbonate-secreting organisms, including Prinsiosphaera (Clémence et al., 2010), and calcareous nannofossils started over with a prolonged recovery. At Pizzo Mondello, the proportion of carbonate produced by calcareous nannofossils in the Pliensbachian, some $10 \mathrm{Myr}$ after the Triassic-Jurassic extinction, was not yet as high as it was at the end of the Triassic.

\subsection{Interpretation of $\delta^{13} \mathrm{C}$ values: admixture of seawater and marine burial diagenetic signals}

In fine-grained carbonate sediments as those of this study, microspar forms during shallow burial as the metastable aragonite dissolves and reprecipitates as low-Mg calcite. 


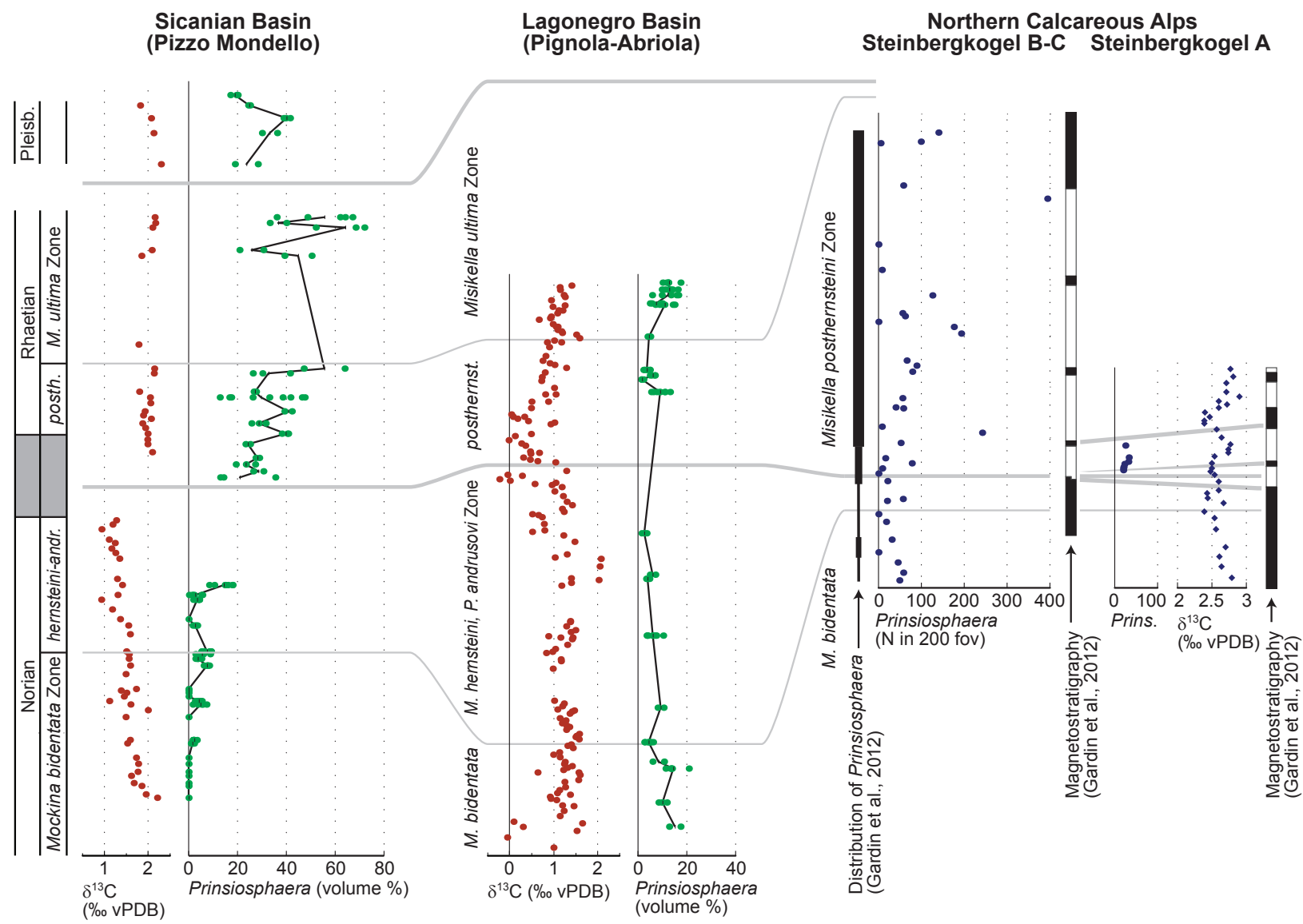

Fig. 9. Correlation of isotopic and nannofossil records between Pizzo Mondello, Pignola-Abriola and Steinbergkogel (Gardin et al., 2012). The correlation with Steinbergkogel is only based on conodont biostratigraphy, and it could thus be inaccurate, as highlighted by Giordano et al. (2010). Distribution of Prinsiosphaera and magnetostratigraphy at Steinbergkogel are reported as in Gardin et al. (2012). Blue dots are obtained from Table 4 in Gardin et al. (2012). Stable carbon isotopes from Krystyn et al. (2007). FOV: fields of view.

This process is well documented on the periplatform carbonates off the Great Bahama Bank (Lasemi and Sandberg, 1984; Melim et al., 1995; Munnecke et al., 1997; Westphal, 2006) and was then recognized in numerous Phanerozoic fine-grained limestone successions as, among others, the Silurian of Gotland (Munnecke et al., 1997), the Upper Triassic of southern Italy (Preto et al., 2009, 2013), the Upper Jurassic of southern Germany (Munnecke and Westphal, 2004; Munnecke et al., 2008). In the best-studied case of the periplatform deposits of the Bahamas, aragonite derives from shallow-water environments of the Great Bahama Bank platform top, and is then exported in surrounding periplatform successions by processes such as density cascading (Wilson and Roberts, 1995). Since aragonite derives from platforms, while calcite derives mainly from tests of planktonic organisms (coccolitophorids and planktonic foraminifera), the aragonite / calcite ratio is a measure of platform-derived sediment in these environments (e.g., Droxler and Schlager, 1985; Reijmer et al., 1988; Schlager et al., 1994) and since carbonate sediment comes either from the carbonate platform or from the photic zone of the open ocean, the carbon isotope composition of the original sediments is inherited fully from shallow waters. Also within the periplatform carbonate sediments of the Bahamas, microspar was interpreted as the product of dissolution of shallow-water aragonite, and its immediate reprecipitation as calcite (Munnecke et al., 1997). Here, microspar maintained the carbon isotope composition of its precursor sediment (Melim et al., 2001) because reprecipitation occurred in pore waters whose composition was not altered with respect to the initial seawater.

The sedimentation environment of the Lagonegro and Sicanian basins should not have been different, especially during the late Triassic, when calcareous nannofossils existed in rock-forming amounts (Preto et al., 2012; 2013; Rigo et al., 2012a). There is evidence of nearby carbonate platforms exporting carbonate into basins, both for the Lagonegro Basin (e.g., Miconnet et al., 1983; Bertinelli et al., 2005; Passeri et al., 2005; Rigo et al., 2007) and Pizzo Mondello (Rigo et al., 2012b). We thus assume that the microsparitic component associated with calcareous nannofos- 
sils derived, in both sections, from shallow-water aragonitic sediment, dissolved and reprecipitated in the marine burial diagenetic environment (Melim et al., 1995). It cannot be assumed that the isotopic composition of carbon in the pore water was the same of seawater (as is the case in the Bahamas, Melim et al., 2001), because organic matter has been buried along with Triassic carbonate sediments.

The carbon isotope data of Pignola-Abriola show a negative excursion close to the Norian-Rhaetian boundary, followed by an increase of the $\delta^{13} \mathrm{C}_{\text {carb }}$ during the Rhaetian (Fig. 3). This pattern is not in contradiction with the incomplete isotopic record of Pizzo Mondello, but was not identified in the Steinbergkogel section (Figs. 2 and 9), which has been proposed for the GSSP of the Rhaetian stage (Krystyn et al., 2007). The $\delta^{13} \mathrm{C}$ of bulk lime mudstone $\left(\delta^{13} \mathrm{C}_{\text {carb }}\right)$ is correlated with nannofossil abundance in both sections (Fig. 8). We propose that this correlation reflects the admixture of carbonate from nannofossils, essentially carrying the unaltered carbon isotope composition of sea-surface waters, with carbonate of the microspar, which incorporated respired organic carbon during shallow burial, when microspar crystals precipitated.

If the microspar component of lime mudstone incorporated light carbon from the respiration of organic matter, this would have lowered its $\delta^{13} \mathrm{C}$, and could explain the correlation between the content of calcareous nannofossils and the carbon isotope composition of limestones. Only calcareous nannofossils retained a pristine seawater $\delta^{13} \mathrm{C}$, while the bulk carbonate registered the admixture of a pristine carbon isotope signal of seawater (carried by calcareous nannoplankton) and a $\delta^{13} \mathrm{C}$ lowered by respired carbon (carried by microspar). The lower $\delta^{13} \mathrm{C}$ and $\delta^{18} \mathrm{O}$ values of PignolaAbriola, which are also strongly correlated, are explained by a higher proportion of incorporated organic carbon and reprecipitation that was completed at higher depths, and thus higher burial temperatures, than at Pizzo Mondello. Higher burial temperatures, which are also suggested by a higher color alteration index (CAI) of conodonts at Pignola-Abriola with respect to Pizzo Mondello (Giordano et al., 2010; Rigo et al., 2012b), drove the $\delta^{18} \mathrm{O}$ to lower values (e.g., Allan and Matthews, 1982; Marshall, 1992).

Alternative interpretations are possible. For example, the increase of $\delta^{13} \mathrm{C}$ in the upper part of the Pignola-Abriola section and the high $\delta^{13} \mathrm{C}$ values (ca. $2 \%$ ) of the upper Pizzo Mondello section may be due to a long-lasting rise of sea-surface productivity during the late Rhaetian. High sea-surface productivity conditions are able to store large amounts of isotopically light organic carbon sinking through the water column, eventually leaving surface waters enriched in ${ }^{13} \mathrm{C}$. The ${ }^{13} \mathrm{C}$-enriched isotopic signature of surface waters is then recorded by calcareous nannofossils, such as, in this case, Prinsiosphaera. The abundance of Prinsiosphaera mirrors the increase in $\delta^{13} \mathrm{C}$ values and this could suggest a direct relationship between sea-surface productivity and abundance of Prinsiosphaera, but a better understanding of the paleoecological affinity of Prinsiosphaera is needed to use the abundance of this taxon as a proxy for sea-surface productivity. Furthermore, this explanation cannot account for the $\delta^{13} \mathrm{C}$ values of ca. 0 to $1.5 \%$ registered in the PignolaAbriola section, which are lower than the ca. $2 \%$ carbon isotope composition of late Norian and Rhaetian Triassic seawater (Korte et al., 2005). Although changes in surface productivity may explain the carbon isotope excursions observed in the studied sections, we believe that additional evidence should be produced, as, for example, measurements of preserved organic matter in sediments (TOC) or other geochemical proxies independent from the abundance of nannofossils, because their uncertain taxonomic affinity renders them unreliable as proxies for oceanographic parameters in the late Triassic.

In short, the $\delta^{13} C_{\text {carb }}$ record of Pizzo Mondello and Pignola-Abriola mostly documents diagenetic processes. All lime mudstones made of coarse $(10-30 \mu \mathrm{m})$ microspar should be considered with caution (Preto et al., 2009), as microspar forms during burial and most probably also incorporates a burial diagenetic carbon isotope signal. More generally, the $\delta^{13} \mathrm{C}_{\text {carb }}$ of bulk rock should not be considered a proxy for the $\delta^{13} \mathrm{C}$ of seawater unless a solid petrographic study is provided in support of this assumption.

Stable isotope records of Triassic successions based on bulk carbonate, as given by, to name a few, Payne et al. (2004), Horacek et al. (2007), Muttoni et al. (2004) and Mazza et al. (2010), and, in part, Korte et al. (2005), should thus be interpreted with extreme caution in the absence of an adequate discussion of diagenetic processes. Once the precipitation of carbonate in the pelagic realm becomes firmly established, deep-water lime mudstones may instead be mostly made of calcareous plankton, and should retain the seawater $\delta^{13} \mathrm{C}$ more easily. Our study shows that the late Rhaetian Misikella ultima biochronozone is perhaps the first time in Earth history when this could have happened.

\section{Conclusions}

Prinsiosphaera, an incertae sedis late Triassic calcareous nannofossil forming characteristic solid "calcispheres", is a major contributor to deep-water carbonate sedimentation in western Tethys, and can constitute up to $60 \% \mathrm{ca}$. of the rock volume in hemipelagic lime mudstones of latest Triassic (late Rhaetian) age. In the studied sections of southern Italy, its first common occurrence in lime mudstones is dated to the late Norian (late Triassic), within the Mockina bidentata conodont biochronozone.

Upper Rhaetian lime mudstones are constituted in significant proportion by Prinsiosphaera both in the Lagonegro and the Sicanian Basin sections (southern Italy). The latest Triassic was thus the first time in Earth history when calcareous plankton reached rock-forming abundances, a condition that started up the so-called "mid-Mesozoic revolution" of Ridg- 
well (2005), i.e., the permanent stabilization of the long-term carbon cycle in the oceans by the initiation of a pelagic carbonate factory.

The increase of calcareous nannofossils in the late Triassic coincided with a positive shift of the $\delta^{13} \mathrm{C}$ of bulk carbonate. However, this does not represent a pristine seawater isotopic signal but rather a diminishing contribution of microspar, which incorporated respired organic carbon during diagenesis, as the proportion of nannofossils increases. We suggest that a similar diagenetic influence should be observed in most Mesozoic isotope records from bulk carbonate, and could only be excluded by careful petrographic examinations.

Acknowledgements. Petra Witte (Department of Geosciences, Bremen), Monika Segl (MARUM, Bremen) and Sebastian Flotow (ZMT, Bremen) assisted in the labs. Stefano Borello (Padova) prepared most of the isotope samples.

Alda Nicora, Michele Mazza (Milano) and Guido Roghi (IGGCNR Padova) helped in the field. Pietro Di Stefano gave insights on the stratigraphy and paleogeography of Sicily. This study was funded by the Alexander von Humboldt Foundation (to NP), by the University of Padova (Progetto d'Ateneo CPDA090175/09 to MR) and by the MIUR (Prin 2008BEF5Z7_005).

Edited by: W. Kiessling

\section{References}

Allan, J. R. and Matthews, R. K.: Isotope signatures associated with early meteoric diagenesis, Sedimentology, 29, 797-817, 1982.

Amodeo, F.: Il Triassico terminale - Giurassico del Bacino Lagonegrese. Studi stratigrafici sugli Scisti Silicei della Basilicata (Italia Meridionale), Mémoirs de Géologie (Lousanne), 33, 1-121, 1999.

Balini, M., Krystyn, L., Levera, M., and Tripodo, A.: Late CarnianEarly Norian ammonoids from the GSSP candidate section Pizzo Mondello (Sicani Mountains, Sicily), Riv. Ital. Paleontol. Stratigr., 118, 47-84, 2012.

Bazzucchi, P., Bertinelli, A., Ciarapica, G., Marcucci, M., Passeri, L., Rigo, M., and Roghi, G.: The Late Triassic-Jurassic stratigraphic succession of Pignola (Lagonegro-Molise Basin, Southern Apennines, Italy, Boll. Soc. Geol. Ital., 124, 143-153, 2005.

Bellanca, A., Di Stefano, E., Di Stefano, P., Erba, E., Neri, R., and Pirini Radrizzani, C.: Ritrovamento di "Calcisfere" e nannofossili calcarei in terreni carnici della Sicilia, Paleopelagos, 3, 9196, 1993.

Bellanca, A., Di Stefano, P., and Neri, R.: Sedimentology and isotope geochemistry of Carnian deep-water marl/limestone deposits from the Sicani Mountains, Sicily: environmental implications and evidence from planktonic source of lime mud, Palaeogeogr. Palaeocl., 114, 111-129, 1995.

Bertinelli, A., Ciarapica, G., De Zanche, V., Marcucci, M., Mietto, P., Passeri, L., Rigo, M., and Roghi, G.:. Stratigraphic evolution of the Triassic-Jurassic Sasso di Castalda succession (Lagonegro basin, Southern Apennines, Italy), Boll. Soc. Geol. Ital., 124, 161-175, 2005.
Bown, P. R.: Calcareous Nannofossil Biostratigraphy, Kluwer Academic, Dordrecht, 1998.

Bown, P. R., Lees, J. A., and Young, J. R.: Calcareous nannoplankton evolution and diversity through time, in: Coccolithophores - from molecular processes to global impact, Springer Verlag, Berlin, 481-505, 2004.

Bralower, T. J., Bown, P. R., and Siesser, W. G.: Significance of Upper Triassic nannofossils from the Southern Hemisphere (ODP Leg 122, Wombat Plateau, N.W. Australia), Mar. Micropaleontol., 17, 119-154, 1991.

Chayes, F.: Petrographic modal analysis, Wiley, London, 1951.

Chayes, F.: The theory of thin-section analysis, J. Geol., 62, 92-101, 1954.

Clémence, M. E., Gardin, S., Bartolini, A., Paris, G., Beaumont, V., and Guex, J.: Bentho-planktonic evidence from the Austrian Alps for a decline in sea-surface carbonate production at the end of the Triassic, Swiss J. Geosci., 103, 293-315, 2010.

Di Nocera, S. and Scandone, P.: Triassic nannoplankton limestones of deep basin origin in the central mediterranean region, Palaeogeogr. Palaeocl., 21, 101-111, 1977.

Di Stefano, P.: The Triassic of Sicily and the Southern Appennines, Boll. Soc. Geol. Ital., 109, 21-37, 1990.

Di Stefano, P., Alessi, A., and Gullo, M.: Mesozoic and Paleogene megabreccias in Southern Sicily: new data on the Triassic paleomargin of the Siculo-Tunisian Platform, Facies, 34, 101-122, 1996.

Droxler, A. W. and Schlager, W.: Glacial versus interglacial sedimentation rates and turbidite frequency in the Bahamas, Geology, 13, 799-802, 1985.

Erba, E.: Calcareous nannofossils and Mesozoic oceanic anoxic events, Mar. Micropaleontol., 52, 85-106, 2004.

Erba, E. and Tremolada, F.: Phytoplankton response to nitrification episodes, atmospheric $\mathrm{CO}_{2}$, and anoxia, Paleoceanography, 19 , PA1008, doi:10.1029/2003PA000884, 2004.

Furin, S., Preto, N., Rigo, M., Roghi, G., Gianolla, P., Crowley, J., and Bowring, S. A.: A high-precision $\mathrm{U} / \mathrm{Pb}$ zircon age from the Triassic of Italy - implications for the Carnian rise of calcareous nannoplancton and dinosaurs, Geology, 34, 1009-1012, 2006.

Gardin, S., Krystyn, L., Richoz, S., Bartolini, A., and Galbrun, B.: Where and when the earliest coccolithophores?, Lethaia, 45, 507-523, 2012.

Giordano, N., Rigo, M., Ciarapica, G., and Bertinelli, A.: New biostratigraphical constraints for the Norian / Rhaetian boundary: data from Lagonegro Basin, Southern Apennines, Italy, Lethaia 43, 573-586, 2010.

Giordano, N., Ciarapica, G., Bertinelli, A., and Rigo, M.: The Norian-Rhaetian interval in two sections of the Lagonegro area: the transition from carbonate to siliceous deposition, Ital. J. Geosci., 130, 380-393, 2011.

Gullo, M.: Conodont biostratigraphy of uppermost Triassic deepwater calcilutites from Pizzo Mondello (Sicani Mountains): evidence for Rhaetian pelagites in Sicily, Palaeogeogr. Palaeocl., 126, 309-323, 1996.

Korte, C., Kozur, H. W., and Veizer, J.: $\delta^{13} \mathrm{C}$ and $\delta^{18} \mathrm{O}$ values of Triassic brachiopods and carbonate rocks as proxies for coeval seawater and palaeotemperature, Palaeogeogr. Palaeocl., 226, 287306, 2005.

Kozur, H. and Mock, R.: New Middle Carnian and Rhaetian conodonts from Hungary and the Alps, stratigraphic importance and 
tectonic implications for the Buda Mountains and adjacent areas, Jb. Geol. Bundesanst., 134, 271-297, 1991.

Krystyn, L., Bouquerel, H., Kuerschner, W., Richoz, S., and Gallet, Y.: Proposal for a candidate GSSP for the base of the Rhaetian stage, New Mexico Museum of Natural History and Science Bulletin, 41, 189-199, 2007.

Horacek, M., Brandner, R., and Abart, R.: Carbon isotope record of the P/T boundary and the Lower Triassic in the Southern Alps: Evidence for rapid changes in storage of organic carbon, Palaeogeogr. Palaeocl., 252, 347-354, 2007.

Lasemi, Z. and Sandberg, P. A.: Transformation of aragonitedominated lime muds to microcrystalline limestones, Geology, 12, 420-423, 1984.

Marshall, J. D.: Climatic and oceanographic isotopic signals from the carbonate rock record and their preservation, Geol. Mag., 129, 151-162, 1992.

Mazza, M., Furin, S., Spötl, C., and Rigo, M.: Generic turnovers of Carnian/Norian conodonts: climatic control or competition? Palaeogeogr. Palaeocl., 290, 120-137, 2010.

Mazza, M., Rigo, M., and Gullo, M.: Taxonomy and biostratigraphic record Upper Triassic conodonts of the Pizzo Mondello section (Western Sicily, Italy), GSSP candidate for the base of the Norian, Riv. Ital. Paleontol. Stratigr., 118, 85-130, 2012.

Melim, L. A., Swart, P. K., and Maliva, R. G.: Meteoric-like fabrics forming in marine waters: Implications for the use of petrography to identify diagenetic environments, Geology, 23, 755-758, 1995.

Melim, L. A., Swart, P. K., and Maliva, R. G.: Meteoric and marineburial diagenesis in the subsurface of Great Bahama Bank, SEPM Spec. Publ. 70, 137-161, 2001.

Mette, W., Elsler, A., and Korte, C.: Palaeoenvironmental changes in the Late Triassic (Rhaetian) of the Northern Calcareous Alps: Clues from stable isotopes and microfossils. Palaeogeogr. Palaeocl., 350-352, 62-72, 2012.

Miconnet, P., Ciarapica, G., and Zaninetti, L.: Faune a Foraminifères du Trias supérieur d'affinité sud-Tethysienne dans l'Apennin méridional (Bassin de Lagonegro, province de Potenza, Italie); comparaison avec l'Apennin septentrional, Rev. Paléobiol., 2, 131-147, 1983.

Munnecke, A. and Westphal, H.: Shallow-water aragonite recorded in bundles of limestone-marl alternations - the Upper Jurassic of SW Germany, Sed. Geol., 164, 191-202, 2004.

Munnecke, A., Westphal, H., Reijmer, J. J. G., and Samtleben, C.: Microspar development during early marine burial diagenesis: a comparison of Pliocene carbonates from the Bahamas with Silurian limestones from Gotland (Sweden), Sedimentology, 44, 977-990, 1997.

Munnecke, A., Westphal, H., and Kölbl-Ebert, M.: Diagenesis of plattenkalk: examples from the Solnhofen area (Upper Jurassic, southern Germany), Sedimentology, 55, 1931-1946, 2008.

Muttoni, G., Kent, D. V., Olsen, P. E., Di Stefano, P., Lowrie, W., Bernasconi, S. M., and Hernandez, F. M.: Tethyan magnetostratigraphy from Pizzo Mondello (Sicily) and correlation to the Late Triassic Newark astrochronological polarity time scale, Geol. Soc. Am. Bull., 116, 1034-1058, 2004.

Passeri, L., Bertinelli, A., and Ciarapica, G.: Palaeogeographic meaning of the late Triassic-Early Jurassic Lagonegro units, Boll. Soc. Geol. Ital., 124, 231-245, 2005.
Payne, J. L., Lehrmann, D. J., Wei, J., Orchard, M. J., Schrag, D. P., and Knoll, A. H.: Large perturbations of the carbon cycle during recovery from the End-Permian extinction. Science, 305, 506509, 2004.

Preto, N., Spötl, C., and Guaiumi, C.: Evaluation of bulk carbonate $\delta^{13} \mathrm{C}$ data from Triassic hemipelagites and the initial composition of carbonate mud, Sedimentology, 56, 1329-1345, 2009.

Preto, N., Rigo, M., Agnini, C., Bertinelli, A., Guaiumi, C., Borello, S., and Westphal, H.: Triassic and Jurassic calcareous nannofossils of the Pizzo Mondello section: a SEM study, Riv. Ital. Paleontol. Stratigr., 118, 131-141, 2012.

Preto, N., Willems, H., Guaiumi, C., and Westphal, H.: Onset of significant pelagic carbonate accumulation after the Carnian Pluvial Event (CPE) in the western Tethys, Facies, doi:10.1007/s10347012-0338-9, 2013.

Reijmer, J. J. G., Schlager, W., and Droxler, A. W.: Site 632: Pliocene-Pleistocene Sedimentation Cycles in a Bahamian Basin, in: Proc. of the ODP Sci. Results, edited by: Austin, J. A. J. and Schlager, W., 166, 213-220, 1988.

Ridgwell, A.: A mid Mesozoic revolution in the regulation of ocean chemistry. Mar. Geol., 217, 339-357, 2005.

Rigo, M., De Zanche, V., Gianolla, P., Mietto, P., Preto, N., and Roghi, G.: Correlation of Upper Triassic sections throughout the Lagonegro Basin, Boll. Soc. Geol. Ital., 124, 293-300, 2005.

Rigo, M., Preto, N., Roghi, G., Tateo, F., and Mietto, P.: A CCD rise in the Carnian (Upper Triassic) of western Tethys, deep-water equivalent of the Carnian Pluvial Event, Palaeogeogr. Palaeocl., 246, 188-205, 2007.

Rigo, M., Preto, N., Franceschi, M., and Guaiumi, C.: Stratigraphy of the Carnian -Norian Calcari con Selce Formation in the Lagonegro Basin, Southern Apennines, Riv. Ital. Paleontol. Stratigr., 118, 143-154, 2012a.

Rigo, M., Trotter, J., Preto, N., and Williams, I.: Isotopic evidence of Late Triassic monsoonal upwelling in the northwestern Tethys, Geology, 40, 515-518, $2012 \mathrm{~b}$.

Scandone, P.: Studi di geologia lucana: la serie calcareo-silicomarnosa, Bollettino della Società dei Naturalisti di Napoli, 76 1-175, 1967.

Schlager, W., Reijmer, J. J. G., and Droxler, A.: Highstand shedding of carbonate platforms, J. Sed. Res., B64, 270-281, 1994.

Spötl, C. and Vennemann T. W.: Continuous-flow isotope ratio mass spectrometric analysis of carbonate minerals, Rapid Commun. Mass Spectrom., 17, 1004-1006, 2003.

Van der Plas, L. and Tobi, A. C.: A chart for judging the reliability of point counting results, Am. J. Sci., 263, 87-90, 1965.

Westphal, H.: Limestone-marl alternations as environmental archives and the role of early diagenesis: a critical review, Int. J. Earth Sci., 95, 947-961, 2006.

Wilson, P. A. and Roberts, H. H.: Density cascading - off-shelf sediment transport, evidence and implications, Bahama Banks, J. Sed. Res., 65, 45-56, 1995.

Young, J. R. and Ziveri, P.: Calculation of coccolith volume and its use in calibration of carbonate flux estimates, Deep Sea Res. II, 47, 1679-1700, 2000.

Zeebe, R. E. and Westbroek, P.: A simple model for the $\mathrm{CaCO}_{3}$ saturation state of the ocean: the "Strangelove", the "Neritan", and the "Cretan" Ocean, Geochem. Geophy. Geosy., 4, 1-26, 2003. 